\title{
Formulation of Payasam with Germinated Buckwheat Milk
}

\author{
K. Shreeja ${ }^{1 *}$, S. Suchiritha Devi ${ }^{1}$, W. Jessie Suneetha ${ }^{1}$ and B. Neeraja Prabhakar ${ }^{2}$ \\ ${ }^{1}$ Department of Foods \& Nutrition, ${ }^{2}$ Department of Horticulture, College of Agriculture, \\ Professor Jayashankar Telangana State Agricultural University, Rajendranagar, \\ Hyderabad 500030, India
}

*Corresponding author

\section{A B S T R A C T}

\section{Keywords}

Germinated

buckwheat,

Buckwheat milk,

Payasam

Article Info

Accepted:

10 January 2019

Available Online:

10 February 2019
Germination is an effective process to improve sensory properties, nutrients and can decrease the anti-nutrient contents of the seeds. Buckwheat is rich in fibre, phenolic compounds and protein of balanced aminoacid composition. The aim of the present work was to evaluate the suitability of germinated buckwheat milk for development of traditional recipe i.e. payasam. Three types of formulations were prepared with germinated buckwheat milk ranged from 25, 50 and 75\%. These products were evaluated for sensory attributes. Payasam prepared with $100 \%$ milk was served as control. Evaluation resulted that addition of $25 \%$ of germinated buckwheat milk was more acceptable.

\section{Introduction}

The family Polygonaceae is a group of plants composed by approximately 1200 species. Buckwheat, which belongs to this family, is found almost everywhere but grows mainly in the northern hemisphere. Russia and China are the main producers of buckwheat in the world. The consumption has become increasingly popular in the United States, Canada, and Europe. Among the main nine species with agricultural meaning, common buckwheat (Fagopyrum esculentum Moench) and tartary buckwheat (Fagopyrum tataricum
Gaertn.) are the most widely grown species (Gimenez-Bastida and Zielinski, 2015).

Buckwheat seeds are the main form of consumption of pseudocereal.

These seeds are principally used for human consumption as breakfast cereals or as processed flour for making different bakery products (bread, cookies, snacks, and noodles) enriched with buckwheat flour $(0.3-60 \%)$ and buckwheat enhanced nonbakery products (tea, honey, tarhana, and sprouts) (Saturni, 2010). 
Buckwheat is recognized as a good source of nutritionally valuable protein, lipid, dietary fiber, and minerals, and in combination with other health-promoting components, such as phenolic compounds and sterols, it has received increasing attention as a potential functional food. Functional foods are those that exert a scientifically proven specific health benefit (health claim) beyond their nutritional properties, although the consumption of its specific formulation is not essential for human life (Krkoskova and Mrazova, 2005).

Zhang et al., (2007) described that the consumption of buckwheat and buckwheatenriched products is related to a wide range of biological and healthy activities: hypocholesterolemic, hypoglucemic, anticancer, and anti-inflammatory. Processing can modify the polyphenol content of foods in several ways. In particular, sprouting has been reported as a means of increasing the polyphenol content of buckwheat seeds.

\section{Materials and Methods}

\section{Procurement of raw materials}

Buckwheat was procured from Assam Agricultural University, Jorhat. All the other ingredients used for the study vermicelli, milk, sugar, ghee, cardamom and dry nuts were obtained from local markets.

\section{Processing of germinated buckwheat milk(GBM)}

The grain was cleaned and soaked in distilled water for 12 hours and spread on Whattman filter paper in trays and covered with the filter paper to hydrate the seeds by capillarity. Trays were incubated at $30^{\circ} \mathrm{C}$ in a dark chamber for 48hours. Then the sprouts were grinded, squeezed and obtained milk was used for development of the germinated buckwheat milk payasam (GBMP).

\section{Preparation of payasam}

Present study was carried out to develop a product with different combinations of milk and germinated buckwheat milk. Three different compositions of payasam was prepared (Control: $100 \%$ milk payasam; GBMP $_{1}: 75 \%$ milk+ 25\% GBM; GBMP 2 : $50 \%$ milk $+50 \%$ GBM; $\mathrm{GBMP}_{3}: 25 \%$ milk+ $75 \%$ GBM) and subjected to sensory evaluation. Payasam was prepared by roasting the vermicelli with little ghee milk was heated and sugar was added. To the boiling milk roasted vermicelli was added and cooked. Cardamom and dry nuts were added finally.

\section{Sensory evaluation of payasam}

A semi-trained panel of 15 members from PG\&RC, PJTSAU using 9 point hedonic scale evaluated the products for colour, texture, flavour, taste and overall acceptability. Scores were based on a hedonic scale of 1 to 9 where: $1=\mathrm{I}$ dislike extremely (very bad) and 9 $=$ I like extremely (excellent) (Meilgaard $e t$ al., 1999). The samples were presented in plates coded with three digit numbers in individual booths in sensory evaluation lab. Panelists rinsed their mouth with water after testing each sample.

\section{Statistical analysis}

All the analysis was performed in replications and the results were presented as mean \pm standard deviation. Difference between the variables was tested for significance by (ANOVA) using SAS version 9.1.

\section{Results and Discussion}

The mean sensory scores of payasam prepared with germinated buckwheat milk were presented in Table 1.The sensory attributes of payasam was plotted in Figure 1. The mean sensory scores of color for 
germinated buckwheat milk payasam ranged from 7.46 \pm 0.91 to $8.66 \pm 0.48$. Among incorporated varieties best mean scores of color was for payasam at $25 \%$ incorporation $(8.60 \pm 0.73)$ and the least for $75 \%$ GBM incorporation $(7.46 \pm 0.91)$. GBMP $_{1}$ (8.60) was significantly on par with the control (8.66).

The mean scores of texture increased from $6.40 \pm 0.82$ to $8.53 \pm 0.51$ (Table 1). The control sample had the highest score $(8.53 \pm 0.51)$ followed by $\mathrm{GBMP}_{1}(8.40 \pm 0.82), \mathrm{GBMP}_{2}$ $(7.00 \pm 0.75)$ while $\mathrm{GBMP}_{3}(6.40 \pm 0.82)$ had least score with $75 \%$ incorporation. The mean sensory scores for taste ranged from $8.80 \pm 0.41$ to $6.53 \pm 0.83$. The control sample had the highest score $(8.80 \pm 0.41)$ followed by $\mathrm{GBMP}_{1} \quad(8.46 \pm 0.51), \quad \mathrm{GBMP}_{2} \quad(6.53 \pm 0.83)$ while $\mathrm{GBMP}_{3}$ had least mean score for taste.

The mean scores of flavor for payasam varied from $8.46 \pm 0.83$ to $7.13 \pm 1.06$ (Table 1). $\mathrm{GBMP}_{1}$ scored highest $(8.46 \pm 0.83)$ followed by control $(8.20 \pm 0.41), \mathrm{GBMP}_{2}(7.53 \pm 0.83)$, while $\mathrm{GBMP}_{3}$ had least mean score for flavor but it was significantly on par with $\mathrm{GBMP}_{2}$
Incorporation of germinated buckwheat milk has added more flavor to payasam.

The mean scores of overall acceptability for payasam increased from 6.86 to 8.33 . The control had highest mean score for overall acceptability $(8.66 \pm 0.48)$ followed by $\mathrm{GBMP}_{1}$ $(8.33 \pm 0.81), \mathrm{GBMP}_{2}(7.33 \pm 0.97)$, whereas $\mathrm{GBMP}_{3}(6.86 \pm 0.91)$ had lowest mean score for overall acceptability. The mean scores of the control were significantly differed with $\mathrm{GBMP}_{2}$ and $\mathrm{GBMP}_{3}$ for colour, texture, taste, flavor and overall acceptability $(\mathrm{p} \leq 0.05)$. The mean scores of all sensory attributes have increased with decrease in percentage of germinated buckwheat flour incorporation.

Sattar et al., (2017) developed the rice pudding with germinated and ungerminated legumes of lentils, black gram and green gram at 5, 15 and $25 \%$ of milk. Rice pudding incorporation with $5-25 \%$ green gram, 5\% lentils and black gram upon germination showed peak viscosity similar to that of the control, suggesting that the germinated seeds could be incorporated into pudding.

Table.1 Mean sensory scores of GBMP

\begin{tabular}{|l|l|l|l|l|l|}
\hline Payasam & Colour & Texture & Taste & Flavor & Overall acceptability \\
\hline Control & $8.66^{\mathrm{a}} \pm 0.48$ & $8.53^{\mathrm{a}} \pm 0.51$ & $8.80^{\mathrm{a}} \pm 0.41$ & $8.20^{\mathrm{a}} \pm 0.41$ & $8.66^{\mathrm{a}} \pm 0.48$ \\
\hline BWP $_{\mathbf{1}}$ & $8.60^{\mathrm{a}} \pm 0.73$ & $8.40^{\mathrm{a}} \pm 0.82$ & $8.46^{\mathrm{a}} \pm 0.51$ & $8.46^{\mathrm{a}} \pm 0.83$ & $8.33^{\mathrm{a}} \pm 0.81$ \\
\hline BWP $_{\mathbf{2}}$ & $7.80^{\mathrm{b}} \pm 0.64$ & $7.00^{\mathrm{b}} \pm 0.75$ & $7.13^{\mathrm{b}} \pm 0.88$ & $7.53^{\mathrm{b}} \pm 0.83$ & $7.33^{\mathrm{b}} \pm 0.97$ \\
\hline BWP $_{\mathbf{3}}$ & $7.46^{\mathrm{b}} \pm 0.91$ & $6.40^{\mathrm{c}} \pm 0.82$ & $6.53^{\mathrm{c}} \pm 0.83$ & $7.13^{\mathrm{b}} \pm 1.06$ & $6.86^{\mathrm{c}} \pm 0.91$ \\
\hline Mean & 8.15 & 7.58 & 7.65 & 7.83 & 7.80 \\
\hline CD & 0.48 & 0.36 & 0.41 & 0.48 & 0.42 \\
\hline SE of mean & 0.24 & 0.17 & 0.20 & 0.24 & 0.21 \\
\hline CV $(\%)$ & 8.14 & 6.46 & 7.29 & 8.14 & 7.43 \\
\hline
\end{tabular}

Note: Values are expressed as mean \pm standard deviation of fifteen determinations.

Means within the same column followed by common letter do not significantly differ at $\mathrm{p} \leq 0.05$.

GBMP: germinated buckwheat milk payasam

Control: $100 \%$ milk payasam

$\mathrm{GBMP}_{1}: 75 \%$ milk+ $25 \% \mathrm{GBM}$

$\mathrm{GBMP}_{2}: 50 \%$ milk $50 \%$ GBM

$\mathrm{GBMP}_{3}: 25 \%$ milk $75 \%$ GBM 
Fig.1 Sensory attributes of developed payasam

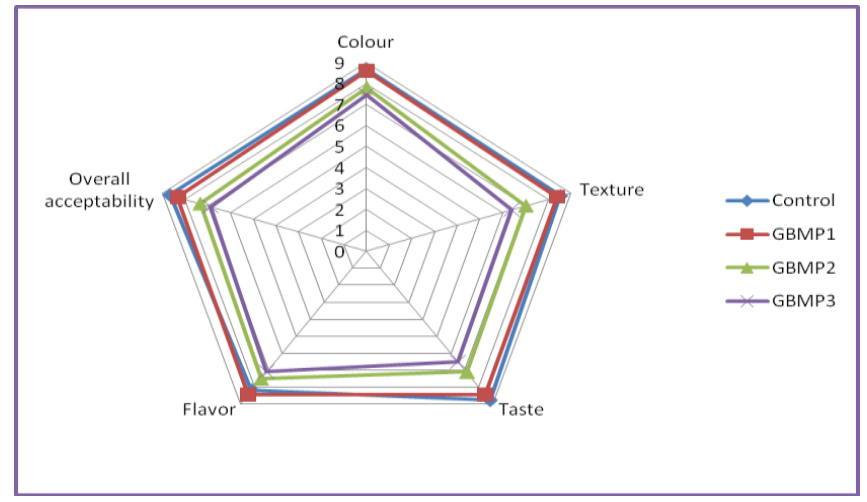

The payasam with $25 \%$ incorporation showed the best score for colour $(8.60 \pm 0.73)$, flavour $(8.46 \pm 0.83), \quad$ taste $(8.46 \pm 0.51)$, texture $(8.40 \pm 0.82)$ and overall acceptability $(8.33 \pm 0.81)$ in comparison to other formulations. The mean scores of the control were on par with $\mathrm{GBMP}_{1}(25 \%$ incorporation) at $\mathrm{p} \leq 0.05$ (Table 1.1). This results shows that $25 \%$ incorporation is suitable for the payasam of germinated buckwheat milk.

Hence, concluded as an attempt was made to improve the sensory and nutritional quality characteristics like minerals and antioxidant activity by substituting germinated buckwheat milk with regular animal milk. The germinated buckwheat payasam at $25 \%$ was found to be the most acceptable among all the products developed from sensory evaluation scores.

\section{References}

Gimenez-Bistada, J.A and Zielinski, H. 2015. Buckwheat as a functional food and its effects on health. Journal of Agricultural and Food Chemistry.63: 7896-7913.
Krkoskova, B and Mrazova, Z. 2005. Prophylactic components of buckwheat. Food Research International. 38 (5): 561-568.

Meilgaard, M. Civille, G.V and Carr, B.T. 1999. Sensory Evaluation Techniques. 3rd Ed. CRC Press, Boca Raton.

Sattar, D.E.S., Ali, T.M and Hasnain, A. 2017. Effect of Nongerminated and Germinated Legumes on Antioxidant, Functional, and Sensory Characteristics of Rice Puddings. Cereal Chemistry. 94(3): 417-423.

Saturni, L., Ferretti, G andBacchetti, T. 2010. The gluten-free diet: safety and nutritional quality. Nutrients. 2(1): 1634.

Zhang, H.W., Zhang, Y.H., Lu, M.J., Tong, W.J and Cao, G.W. 2007.Comparison of hypertension, dyslipidaemia and hyperglycaemia between buckwheat seed-consuming and non-consuming Mongolian-Chinese populations in Inner Mongolia, China. Clinical and Experimental Pharmacology and Physiology. 34 (9): 838-844.

\section{How to cite this article:}

Shreeja, K., S. Suchiritha Devi, W. Jessie Suneetha and NeerajaPrabhakar, B. 2019. Formulation of Payasam with Germinated Buckwheat Milk. Int.J.Curr.Microbiol.App.Sci. 8(02): 948-951. doi: https://doi.org/10.20546/ijcmas.2019.802.109 